\title{
The Implementation of Corporate Governance Through Self-assessment in Increasing Liquidity of East Java Regional Development Bank
}

\section{Eni Wuryaní $i^{1}$, Durinda Puspasari ${ }^{2}$, and Durinta Puspasari ${ }^{2}$}

${ }^{1}$ Accounting Department, Faculty of Economics, Universitas Negeri Surabaya, Surabaya, Indonesia

${ }^{2}$ Economic Education Department, Faculty of Economics, Universitas Negeri Surabaya, Surabaya, Indonesia

\section{Abstract}

This study will analyze the application of Corporate Governance (CG) in increasing liquidity. CG is measured from the self-assessment conducted by the East Java Development Bank. The implementation of corporate governance is based on SEOJK No. 32/SEOJK.04/2015, concerning the open corporate governance. The application

Corresponding Author: Eni Wuryani

eniwuryani@unesa.ac.id

Received: 29 January 2019 Accepted: 27 February 2019 Published: 24 March 2019

Publishing services provided by Knowledge E

(c) Eni Wuryani et al. This article is distributed under the terms of the Creative Commons

Attribution License, which permits unrestricted use and redistribution provided that the original author and source are credited.

Selection and Peer-review under the responsibility of the $3 \mathrm{rd}$ ICEEBA Conference Committee. of CG has eight principles. Liquidity is measured by Current Ratio. This study uses descriptive analysis. Data used financial statements and the implementation of CG in 2017. The results showed that the application of CG based on self-assessment has good criteria. The level of liquidity shows liquid results. This shows that a good implementation of CG will increase the level of liquidity.

Keywords: corporate governance, liquidity, current ratio, self-assessment

\section{Introduction}

Bank Jatim is a bank owned by the East Java provincial government. Bank Jatim obtained the first winner of the 2015 Annual Report Award for the BUMD category. This is a proud achievement for Bank Jatim and is a real commitment of Bank Jatim in the aspect of Good Corporate Governance. Achievements will inspire management to continue to implement good Corporate Governance to be the best for stakeholders and shareholders.

Bank Jatim complies with and complies with every applicable regulatory framework and the Law in Indonesia concerning Good Corporate Governance including: Law of the Republic of Indonesia Number 40 of 2007 concerning Limited Liability Companies, Regulation of the Financial Services Authority Number 55/POJK.03/2016 7 December 
Banks, Financial Services Authority Regulation Number 4/POJK.03/2016 dated January 26, 2016 concerning Appraisal of Commercial Banks. Financial Services Authority Circular Number 13/SEOJK.03/2017 March 17, 2017 Concerning the Implementation of Good Corporate Governance for Commercial Banks. Financial Services Authority Circular Letter Number 32/SEOJK.04/2015 concerning Public Company Governance Guidelines.

\section{Literature Review}

\subsection{Liquidity}

The rules regarding bank liquidity are regulated by regulations issued by the OJK Financial Services Authority Number 42/POJK.03/2015 concerning bank liquidity. Bank liquidity is the ability to pay off liabilities in the short term.

\subsection{Corporate governance}

The application of corporate governance based on SEOJK No. 32/SEOJK.04/2015 concerning the Guidelines for Governance of Public Companies which adapts 8 (eight) principles as follows:

1. Increasing the value of organizing the General Meeting of Shareholders (GMS).

2. Improve the quality of public company communication with shareholders or investors.

3. Strengthening membership and composition of the board of commissioners.

4. Improving the quality of implementation of duties and responsibilities of the board of commissioners.

5. Strengthening the membership and composition of the board of directors.

6. Improving the quality of implementation of the duties and responsibilities of the directors.

7. Implementation corporate governance aspects with stakeholder participation.

8. Carry out information disclosure. 


\subsection{Bank efficiency}

[1] banks in efficient conditions amounted to $95 \%$ when there was a change in the banking system. [1] efficiency in the commercial banking sector reached 80\%. [2] bank efficiency reaches 95\%. Rezitis (2004) growth in productivity and technical efficiency in the banking sector amounted to 91.3\%. [3], the efficiency of the commercial banking sector averaged 95\%. Pathis, Kosmidou and Doumpos (2001), profitability and efficiency in small banks and banks show almost the same results. small companies produce $86.71 \%$ and large companies at $8.35 \%$.

[4] evaluating efficiency from 19 banks, 32\% of banks experienced efficiency and $68 \%$ were inefficient in a global crisis. [5] in 2003-2007 and in 2010-2012 the efficiency of banks increased. The efficiency of banks has declined in 2008-2010, this is due to recession. Bank efficiency research has been carried out by [6-10]. [11] the impact of the global financial crisis on the efficiency of Greek banks in 2009 showed a slight increase in technical efficiency scores. In 2010 there was a decrease in technical efficiency scores.

\section{Methodology}

This study uses descriptive analysis. The data used uses secondary data, namely the Bank Jatim report in 2017 and reports on good corporate governance practices in 2017.

\section{Results and Discussion}

The amount of 2017 current assets is Rp. 50,094,097,000,000 increase of IDR $8,207,263,000,000$ when compared to the same period in 2016 amounting to IDR $41,886,834,000,000$ or an increase of $16.38 \%$. The amount of 2017 short-term liabilities of Rp.43,515,593,000,000 decreased by Rp.7,795,636,000,000 compared to the same period in 2016 of Rp35,719,957,000,000 or a decrease of $17.91 \%$.

Based on 2017 report data shows good results seen that assets increased and current liabilities decreased. The liquidity ratio is measured by the current ratio, namely current assets divided by current debt. The current Bank Jatim ratio is 115\%, Bank Jatim is classified as liquidity. Bank Jatim is able to pay off debt in the short term.

The amount of 2017 net income of Rp1,642,807,000,000 increased by Rp.191,225,000,000 compared to the same period in 2016 of Rp1,451,582,000,000 or an increase of $11.64 \%$. Total profit after tax and before other comprehensive income 
TABLE 1: Short balance sheet report 2016-2017 period PT. Bank Jatim (Persero) TBK.

Information
Asset
Current assets
Assets are not
smooth
Total assets
Liability and
equity
Short-term
liabilities
Long-term
Liabilities
Total Liabilities
Equity
Total Equity
Total Liabilities
and Equity

\begin{tabular}{c} 
Audited 2017 \\
a \\
\hline Rp \\
50,094,097,000,000 \\
Rp 1,424,584,000,000 \\
\hline Rp 51,518,681,000,000 \\
\hline Rp \\
\hline $43,515,593,000,000$ \\
\hline Rp 187,014,000,000 \\
\hline Rp \\
\hline $43,702,607,000,000$ \\
\hline Rp 7,816,074,000,000 \\
\hline Rp 51,518,681,000,000 \\
\hline
\end{tabular}

\begin{tabular}{c} 
Audited 2016 \\
b \\
Rp \\
$41,886,834,000,000$ \\
Rp 1,146,116,000,000 \\
\hline Rp \\
\hline $43,032,950,000,000$ \\
\hline Rp \\
\hline $35,719,957,000,000$ \\
\hline$R p 103,421,000,000$ \\
\hline$R p$ \\
\hline $35,823,378,000,000$ \\
\hline$R p 7,209,572,000,000$ \\
$R p$ \\
\hline $43,032,950,000,000$
\end{tabular}

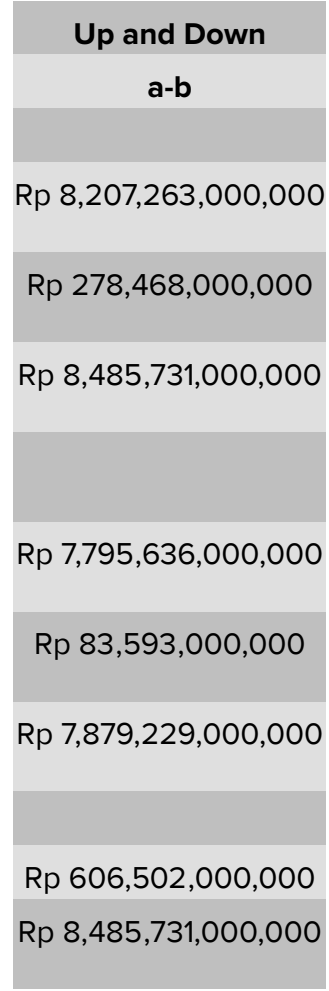

\begin{tabular}{|c|}
\hline \% \\
\hline$(a-b) / a$ \\
\hline $16.38 \%$ \\
\hline $19.55 \%$ \\
\hline $16.47 \%$ \\
\hline $17.91 \%$ \\
\hline $44.70 \%$ \\
\hline $18.03 \%$ \\
\hline $7.76 \%$ \\
\hline $16.47 \%$ \\
\hline
\end{tabular}

in 2017 amounting to $\mathrm{Rp} 1,159,370,000,000$ increased by $\mathrm{Rp} .131,154,000,000$ compared to the same period in 2016 amounting to Rp1,028,216,000,000 or an increase of $11.31 \%$.

The acquisition value of GCG implementation at Jatim bank is 2.2. Based on criteria, the value of GCG is classified as good. The management of Bank Jatim has applied the principles of GCG, based on self-assessment assessment conducted by the bank of East Java. The organizational structure at Bank Jatim is in accordance with the Bank's rules and articles of association. The accountability of the implementation of GCG has been reported at the General Meeting of Shareholders.

\section{Conclusion}

Bank Jatim in 2017 experienced liquidity. Operating profit has increased from the previous year. Bank Jatim has carried out 8 corporate governance principles which have good results. The organizational structure at Bank Jatim has run according to the applicable rules. Stakeholder involvement in the implementation of corporate governance can be seen in the delivery of accountability in the general meeting of shareholders. 
TABLE 2: Short income statement 2016-2017 period PT. Bank Jatim (Persero) TBK.

\begin{tabular}{|c|c|c|c|c|}
\hline \multirow[t]{2}{*}{ Information } & Audited 2017 & Audited 2016 & Up and Down & $\%$ \\
\hline & a & b & $a-b$ & $(a-b) / a$ \\
\hline Net Income & Rp 4,889,674,000,000 & Rp 4,904,378,000,000 & (Rp 14,704,000,000) & $-0.30 \%$ \\
\hline $\begin{array}{l}\text { Main Load and } \\
\text { Direct Load }\end{array}$ & $\begin{array}{c}(\mathrm{Rp} \\
1,404,762,000,000)\end{array}$ & $\begin{array}{c}(\mathrm{Rp} \\
1,446,372,000,000)\end{array}$ & Rp 41,610,000,000 & $-2.96 \%$ \\
\hline Gross Profit & Rp 3,484,912,000,000 & $\begin{array}{c}\mathrm{Rp} \\
3,458,006,000,000\end{array}$ & Rp 26,906,000,000 & $0.77 \%$ \\
\hline $\begin{array}{l}\text { Other Operating } \\
\text { Income }\end{array}$ & Rp 371,186,000,000 & Rp 349,751,000,000 & Rp 21,435,000,000 & $5.77 \%$ \\
\hline $\begin{array}{l}\text { Sales, General } \\
\text { and } \\
\text { Administrative } \\
\text { Expenses }\end{array}$ & $\begin{array}{c}(\mathrm{Rp} \\
2,213,291,000,000)\end{array}$ & $\begin{array}{c}(\mathrm{Rp} \\
2,356,175,000,000)\end{array}$ & Rp $142,884,000,000$ & $-6.46 \%$ \\
\hline $\begin{array}{l}\text { Net Financial } \\
\text { Income }\end{array}$ & Rp $1,642,807,000,000$ & Rp 1,451,582,000,000 & Rp 191,225,000,000 & $11.64 \%$ \\
\hline $\begin{array}{l}\text { Other } \\
\text { Non-business } \\
\text { Income }\end{array}$ & Rp $32,716,000,000$ & Rp 30,646,000,000 & Rp 2,070,000,000 & $6.33 \%$ \\
\hline $\begin{array}{l}\text { Other } \\
\text { Non-business } \\
\text { Expenses }\end{array}$ & (Rp 38,582,000,000) & (Rp 30,100,000,000) & (Rp 8,482,000,000) & $21.98 \%$ \\
\hline Profit Before Tax & Rp $1,636,941,000,000$ & Rp $1,452,128,000,000$ & Rp $184,813,000,000$ & $11.29 \%$ \\
\hline \multicolumn{5}{|l|}{$\begin{array}{l}\text { Tax } \\
\text { Income/Expenses }\end{array}$} \\
\hline Current Tax & 0 & Rp 514,740,000,000 & (Rp 514,740,000,000) & \\
\hline $\begin{array}{l}\text { Deferred Tax } \\
\text { Expense } \\
\text { (Benefits) }\end{array}$ & 0 & $(\operatorname{Rp} 90,828,000,000)$ & Rp 90,828,000,000 & \\
\hline $\begin{array}{l}\text { Amount of Tax } \\
\text { Expense }\end{array}$ & Rp 477,571,000,000 & Rp 423,912,000,000 & Rp 53,659,000,000 & $11.24 \%$ \\
\hline $\begin{array}{l}\text { Current Year Net } \\
\text { Profit }\end{array}$ & Rp 1,159,370,000,000 & Rp 1,028,216,000,000 & Rp 131,154,000,000 & $11.31 \%$ \\
\hline \multicolumn{5}{|l|}{$\begin{array}{l}\text { Other } \\
\text { Comprehensive } \\
\text { Income }\end{array}$} \\
\hline $\begin{array}{l}\text { Fixed Asset } \\
\text { Revaluation } \\
\text { Surplus }\end{array}$ & Rp $112,985,000,000$ & Rp 537,756,000,000 & $(\operatorname{Rp} 424,771,000,000)$ & $-375.95 \%$ \\
\hline $\begin{array}{l}\text { Losses for } \\
\text { Remeasuring the } \\
\text { Defined Benefit } \\
\text { Program }\end{array}$ & (Rp 70,356,000,000) & (Rp 1,612,000,000) & (Rp 68,744,000,000) & $97.71 \%$ \\
\hline Tax Related & Rp 17,589,000,000 & (Rp 21,106,000,000) & Rp 38,695,000,000 & $220.00 \%$ \\
\hline $\begin{array}{l}\text { Total } \\
\text { Comprehensive } \\
\text { Profit }\end{array}$ & Rp 1,219,588,000,000 & Rp $1,543,254,000,000$ & $(\operatorname{Rp~} 323,666,000,000)$ & $-26.54 \%$ \\
\hline
\end{tabular}


TABLE 3: GCG self-assessment GCG December 2017 period.

Assessed Aspects
Implementation of Board of Commissioners Duty
and Responsibility
Implementation of Board of Directors Duty and
Responsibility
Committee's Completeness and Duty
Implementation
Conflict of Interest Handling
Bank's Compliance Function Implementation
Internal Audit Function Implementation
External Audit Function Implementation
Implementation of Risk Management Function
Including Internal Control System
Prudential Banking Principle in Fund Provision to
Relate Party and Large Exposure
Disclosure of Financial and Non-financial
Condition, GCG Report and Internal Reporting
Bank Strategic Plan
GCG COMPOSITE SCORE

\begin{tabular}{|l|}
\hline Value \\
\hline 2 \\
\hline 3 \\
\hline 2 \\
\hline 2 \\
\hline 2 \\
\hline 2 \\
\hline 2 \\
\hline 2 \\
\hline 2 \\
\hline 2 \\
\hline 2
\end{tabular}

\begin{tabular}{|c|}
\hline Weight \\
\hline $10 \%$ \\
\hline $20 \%$ \\
\hline $10 \%$ \\
\hline $10 \%$ \\
\hline $5 \%$ \\
\hline $5 \%$ \\
\hline $5 \%$ \\
\hline $5 \%$ \\
\hline $7.5 \%$ \\
\hline $7.5 \%$ \\
\hline $15 \%$ \\
\hline $100 \%$ \\
\hline
\end{tabular}

\begin{tabular}{c}
$\begin{array}{c}\text { Obtaining } \\
\text { Value }\end{array}$ \\
0.2 \\
0.6 \\
\hline 0.2 \\
\hline 0.2 \\
\hline 0.1 \\
0.1 \\
\hline 0.1 \\
\hline 0.15 \\
\hline 0.15 \\
\hline 0.3 \\
\hline 0.1 \\
\hline 2.2 \\
\hline
\end{tabular}

Composite Value
Composite Score $<1.5$
$1.5 \leq$ Composite Score $<2.5$
$2.5 \leq$ Composite Score $<3.5$
$3.5 \leq$ Composite Score $<4.5$
$4.5 \leq$ Composite Score $<5$

\begin{tabular}{|c|}
\hline $\begin{array}{c}\text { Composite } \\
\text { Predicate }\end{array}$ \\
\hline Very Good \\
\hline Good \\
\hline Fair \\
\hline Less Good \\
\hline Bad \\
\hline
\end{tabular}

\section{References}

[1] Christopoulos, D. K., and Tsionas, E. G. (2001). Banking economic efficiency in the deregulation period: Results from heteroscedastic stochastic frontier models. The Manchester School, vol. 69, pp. 656-676.

[2] Halkos, G. and Salamouris, D. (2004). Efficiency measurement of the Greek commercial banks with the use of financial ratios: A data envelopment analysis approach. Management Accounting Research, vol. 15, pp. 201-224.

[3] Pasiouras, F. (2006). Estimating the technical and scale efficiency of Greek commercial banks: The impact of credit risk, off-balance sheet activities, and international operations. University of Bath, School of Management, 2007, vol. 16. 
[4] Varias, A. and St. Sofianopoulou. (2012). Efficiency evaluation of Greek commercial banks using DEA. Journal of Applied Operational Research, vol. 4, no. 4, pp. 183193.

[5] Kuchler, A. (2013). The efficiency of Danish banks before and during the financial crisis. A comparison of DEA and SFA (Working Papers 2013/87). Danmarks National Bank. Retrieved from: http://www.nationalbanken.dk/C1256BE9004F6416/ side/9BC2299AE14FCD70C1257C3D0062B259/\$file/DNWP\%2087_2013.pdf

[6] Gaganis, C. and Pasiouras, F. (2009). Efficiency in the Greek banking industry: A comparison of foreign and domestic banks. International Journal of the Economics of Business, vol. 16, pp. 221-237.

[7] Georgantopoulos, A. and Tsamis, A. (2013). Assessing the efficiency of commercial banks in Greece during the financial crisis: A linear approach in conjunction with financial analysis. Journal of Money, Investment and Banking, vol. 28, pp. 32-46.

[8] Thalassinos, I. E., Stamatopoulos, Th., and Thalassinos, E. P. (2014). The European sovereign debt crisis and the role of credit swaps, in in W. T. Ziemba and A. G. Malliaris (eds.) The WSPC Handbook of Futures Markets, in the memory of Late Milton Miller (Nobel 1990), World Scientific Handbook in Financial Economic Series Vol. 5.

[9] Thalassinos, E. P. (2014). Credit default swaps and sovereign debt in Eurozone, in D. Milos Sprcic (ed.) Risk Management: Strategies for Economic Development and Challenges in the Financial System, pp. 141-171. New York: Nova Publishers.

[10] Thalassinos, I. E., Liapis, K., and Thalassinos, E. J. (2011). A holistic framework for measuring a bank's financial health. Retrieved from: http://ssrn.com/abstract= 1787626

[11] Papagiannis, G. D. (2014). Measurement of efficiency in Greek banking industries in the light of the financial crisis. European Research Studies, vol. XVII, no. 1, pp. 19-38. 